\title{
Author Correction: Working Style Assessment (WSA): Instrument Adjustment for the Thai Context
}

\author{
Nanta Sooraksa ${ }^{1}$ (D) Oranuch Pruetipibultham $^{1}$ \\ Published online: 12 October 2020 \\ (C) Springer Science+Business Media, LLC, part of Springer Nature 2020
}

\section{Author Correction: Public Organization Review. https://doi.org/10.1007/s11115-020-00484-3}

The original version of this article unfortunately contained a mistake. The name of the 2nd author was incorrectly presented. The correct name of the 2nd author is "Oranuch Pruetipibultham.”

The original article has been corrected.

Publisher's Note Springer Nature remains neutral with regard to jurisdictional claims in published maps and institutional affiliations.

The online version of the original article can be found at https://doi.org/10.1007/s11115-020-00484-3

Nanta Sooraksa

nanta.soo@gmail.com

Oranuch Pruetipibultham juedory@gmail.com

1 School of Human Resource Development, National Institute of Development and Administration (NIDA), 118 Serithai Road, Klong-chan, Bangkapi, Bangkok 10240, Thailand 